\title{
Lapurdum
}

LAPURDUM Euskal ikerketen aldizkaria | Revue d'études basques |

Revista de estudios vascos | Basque studies review

$8 \mid 2003$

Numéro VIII

\section{Euskara berpizteko politika Ipar Euskal Herrian}

\section{Eguzki Urteaga}

URL : http://journals.openedition.org/lapurdum/1178

DOI : $10.4000 /$ lapurdum. 1178

ISSN : 1965-0655

Éditeur

IKER

Édition imprimée

Date de publication : 1 novembre 2003

Pagination : 501-518

ISBN : 9782867813436

ISSN : $1273-3830$

\section{Référence électronique}

Eguzki Urteaga, «Euskara berpizteko politika Ipar Euskal Herrian », Lapurdum [Linean], 8 | 2003, Sarean emana---an 01 juin 2009, kontsultatu 19 avril 2019. URL : http://journals.openedition.org/ lapurdum/1178; DOI : 10.4000/lapurdum. 1178 


\section{Eguzki Urteaga}

\section{Euskara berpizteko politika Ipar Euskal Herrian}

\section{Sarrera}

1. Azken urteetan, soziolinguistika aplikatua garapen berezia ezagutzen ari da. Hainbat lan Ipar Ameriketako ikerlari batzuek inspiratu dituzte Fergusson eta Fishman adibide direla. Beraien pentsamoldea diglosia konzeptuaren inguruan antolatu dute, alegia, komunitate baten barnean kokatzen diren bi hizkuntzen banaketa funtzionala azpimarratuz. Diglosia hitz egiten da hizkuntza banaketa hizkuntza bakoitzaren mugatze argi baten inguruan oinarritzen delarik. Adibidez, A hizkuntza publikoan egiten diren diskurtso formalei lotua zaion bitartean, B hizkuntza etxeko erabilerari josia zaio. Pentsalari horien arabera, praktika soziolinguistikoen ekonomia egonkorra zein orekatua da.

Aitzitik, 70. hamarkadan, Europako ikerlariek diglosia konzeptua egokituko dute bi hizkuntzen arteko konpetentzia eta desberdintasun egoerak adierazteko, ikuspegi aldakorrago bat hobetsiz. Hortik aurrera bi hizkuntzen arteko harreman problematikoan ekiten da zeren : edo hizkuntza nagusia bezain ofiziala pixkanaka baina segurtasunarekin hizkuntza gutxituari trukatuko zaio bere tokia hartuz, edo hizkuntza ezofizialaren hiztunak borrokatuko dira bere berreskurapena segurtatzeko bizi sozialeko arlo guzietara hedatuz.

2. Beste ikerketa batzuk aldiz hizkuntza politikari interesatu dira, jakinik nozio hau ezin daitekela hizkuntza planifikaziotik banatu zeren gizarte batean dauden bi hizkuntzen inguruan burutzen diren ekintza politikoaren bi mailak baitira. Zentzu horretan, hizkuntza planifikazioa hizkuntza politikoak finkatzen dituen kontsiderazio, aukera eta ikuspegien gauzatzea adierazten du instituzioen mailan edo, nahiago bada, zuzenbidearen mailan. Zehazkiago, hizkuntza planifikazioa honela definitu daiteke "hizkuntza arazoak konpontzeko eginak diren saiakera zein indar konziente bezain antolatuak bezela. Erabaki horiek hartuak dira hizkuntza praktika eta jarrera batzuk bultzatzeko eta eragiteko. Hizkuntza baten erabilera nahitara moldatzeko indar multzo bat da". 
Ondorioz hizkuntza politika agertzen zaigu hizkuntza eta bizi sozialaren arteko harremanetan konzienteki eginak diren aukera multzo bat gisa. Hizkuntza planifikazioa ordea, hizkuntza politika baten gauzatzeko behar diren neurrien aurkitzea zein erabakitzea bezela ageri zaigu. Beraz, hizkuntza planifikazioak hizkuntza politika suposatzen badu kontrakoa ez da egia. Hain zuzen ere, gerta daiteke hizkuntza komunitate batek osatu duen hizkuntza politika aplikatzeko ahalmenik ez ukatea edo ez instituzioen bidez gauzatzea. Frantzia modelo honen adibidea da duela hainbat urte hizkuntza politiken arteko gatazken lurra baita. Baina, Estatutik ala gizartetik datozela, soilik azken urteetan itxura juridiko bat hartu dute. Rouquette-ek esaten duen bezala, Frantzian hizkuntza zuzenbidea oraindik sortzen ari da. Funtsezko legeak monarkia eta iraultza garaikoak ala gerla ostekoak dira, nahiz eta azken urteetan garapen nabarmena ezagutu.

3. Eta zer esan dezakegu Frantzian gauzatzen den hizkuntza politikari buruz? Boyer-rek azpimarratzen duen erara, Frantzian, hizkuntza gutxituak serioski hartzen dituen proposamen guziak Estatu aferak bilakatzen dira, nahiz eta tokiko hizkuntza eta dialektoen irakaskuntza legeztatzen duen Deixonne legea onartua izan eta azken urteetan aurrerapausoak egon. Zeren Frantziak hizkuntza gutxituen aurkako ideologia borroka tradizio luze bat baitauka. Errepublikak monarkiaren joera naturala areagotu du zeren ez da soilik hizkuntza gatazkak baretzen saiatu dela baizik eta hizkuntza horien irudi ezkorrak garatu dituela nazioaren alfabetizazioaren izenean. Izan ere, soziolinguista batzuek erakutsi dutenez, patois hitzak, hizkuntzaren ikuspegi negatibo bat dakar. Batik bat Hezkuntza Nazionalaren bidez, praktika glotofagikoa nagusitu da eta are eta eraginkorragoa izan da zilegiztatu baitu legera jo gabe.

Beraz, luzaz, Frantziak hizkuntza gutxituen hizkuntza antolaketa arbuiatu du hizkuntzen arteko gatazka haunditzen utziz frantsesaren mesederako. Alabaina, bi joerek pixkanaka hizkuntza politiken araberako botere publikoen jarrera aldatu dute 70 . hamarkatik landa. Batetik, hizkuntza horien ezagupen ofiziala eta berreskurapena aldarrikatzen duten mugimendu antolatuak sortu dira. Ofizialtasunaz gain, euskararen presentzia oparoagoa eskatzen dute hezkuntza, komunikabide eta zerbitzu publikoetan. Bestetik, inglesaren eragin geroz eta haundiagoa nabaritzen joan da ingles hitzak frantses hiztegian sartuz. Egoera honen aurrean, Frantzia pixkanaka hizkuntza politika bat osatzen eta ondoren gauzatzen hasi da hizkuntza gutxituak babesteko.

4. Baina, interesatzen gaituena da jakitea ea, historiaren pixuaren eta legearen mugez gaindi, euskara sustatzeko eta bultzatzeko hizkuntza politikarik dagoen. Nere hipotesiaren arabera, 90. hamarkada, modu adostuan osa- 
tutako euskararen aldeko hizkuntza politika baten sorreraren sinonimoa da. 1994ean hasi zen Euskal Herria 2010 prospektibarekin, 1997n jarraitu zuen Hizkuntza Antolaketa Eskemarekin eta 2000 urtean gauzatu zen Hitzarmen Bereziako hizkuntza atalarekin. Politika honekin batera erakundeak osatu dira, alde batetik, hizkuntza politika definitu eta gauzatu ahal izateko ahalbideak mobilizatzeko eta, beste aldetik, diagnostikoak osatzeko, proposamenak adierazteko eta adostutako ekintzak ebaluatzeko.

\section{Euskal Herria 2010 Prospektiba}

Euskal Herria 2010 Prospektibak hausnarketa kolcktibo baten hasiera adierazi du Ipar Euskal Herria eta bere hizkuntzaren geroari buruz Euskal Herria 2010 elkartearen barnean. 1992ko irailetik at, CODILen iniziatibari esker, Baionako Suprefetak, tokiko hautetsiek, lanbideetako ordezkariek, funtzionarioek eta elkarteen ordezkariek elkarrekin egoeraren azterketa bat eta ikuspegi prospektibo bat egin zuten, GERPA prospektiban aditua den ikerketa bulegoaren laguntzarekin.

Azterketa honen emaitzak argitaratuak izan dira publikoki aurkeztu diren hiru txostenen bidez. Aurkezpena 1993ko abenduaren 4ean suertatu zen Baionako Industria eta Merkataritza Ganbaran eta txosten horietan aurki daiteke : 1) gaurko egoeraren analisi bat perspektiba historiko baten bidez, bere dimentsio ekonomiko, politiko, sozial eta kulturaletan, 2) azterketa estruktural bat zeinek aldaketa bektoreak, joera nagusiak eta geroko funtsezko neurriak azpimarratzen dituen, 3) prospektiba bat zeinek geroko sei eszenarioak agertarazten dituen. Batek gaurko egoeraren bilakaera jarraitzen badu, besteek suerta daitezken eszenario ezberdinak deskribatzen ditu, beti ere eragileen erabakien arabera.

\section{Euskararen egoeraren diagnostikoa}

Prospektibaren egileen arabera, Ipar Euskal Herriak bere hizkuntzari, kulturari eta historiari lotua dagoen nortasun indartsu bat dauka. Bere lehen aberastasuna hizkuntza da eta, nahiz eta Europako zaharrena izan, hiltzorian dago euskarazko irakaskuntzaren garapena ez baita aski bere erabilpena berpizteko.

Ipar Euskal Herriaren modernizazioa eta euskararen galera. Txostenak dioen moduan, duela gutxi arte Ipar Euskal Herriak bere antolaketa tradizional bezain komunitarioa atxiki du. Modernitatea frantsesari lotua zegoen esan nahi baita modan izateko eta gizarte modernoen arabera ez atzeratua gelditzeko Ipar Euskal Herriko biztanleek frantsesa ikasi behar zutela baita 
euskara ahaztu ere. Ondorioz, elebitasunak esan nahi zuen euskaratik frantsesera igaro behar zela modernitatera pasa nahi izan ezkero. Frantses iraultzak fenomeno hori areagotu du alde instituzional bat emanez zeren euskara XVIII. mendeko pentsakeraren hedapena oztopatzeaz akusatua zegoen. Bestela esanda, modernitateak frantsesa hitzegiten bazuen, sineskeriak euskara erabiltzen zuen.

Ondorioz, XVIII eta XIX. mendeetan euskara gudukatua izan zen eta modernitatearen aukera egiten zutenek euskara utzi behar zuten ez hainbeste bortxatuak zirelako baizik eta ez ziotelako inolako baliogarritasun sozialik ematen. Galera, maila batean, promozio sozialak konpentsatzen zuen. Hala ere, laborari munduan, euskarak nagusi izaten jarraitzen zuen. Elizak euskararen apostua egin zuenez, haustura haunditu zuen frantsesa, modernitatearen eta arrazoiaren hizkuntza eta euskara, tradizioa eta morala komunitarioaren hizkuntzaren artean. Halaber, bertako jauntxoek haustura hori sakondu zuten zeren gizarte tradizionaleko kide izaten jarraitzen bazuten, besteak beste euskararen erabilerari esker, gizarte modernoa oso ongi ezagutzen zuten. Beraz, Ipar Euskal Herriko funtsezko pertsona bat bilakatu zen biztanleriaren eta Estatuaren artean bitartekari errola jokatuz.

Modelo hau nagusitu da baserri mundua modernitatean sartu arte. Euskarak ez zuenez inungo baliorik eta gutxiestearen sinonimoa zenez, euskaldunek beraien hizkuntza sufrimendu bat bezela bizi zuten. Ohartzen ziren baliogabekoa izan arren aberastasun bat suposatzen zuela. Baina askok hainbat apalkuntza eta trufakeri ekarri zien hizkuntza beraien haurrei ez transmititzea erabaki zuten.

\section{Erabilera mugatua eta ikasteko gogoa}

Prospektibaren egileen arabera, garai traumatizante hori amaitu da baita euskara kasik desagertu ere gizarte tradizionalarekin batera. Aitzitik, euskara ikasteko griña berriz agertu da eta ez da garatzen gelditu biztanleak ohartu direnetik euskara galtzeko arrixkuan zegoela eta aberastasun bat errepresentatzen zuela. Oharra kontraesangarria da zeren euskara ez baita inoiz hain gutxi erabilia izan eta inoiz ez baita ikasteko gogo hain haundirik egon. Baina, kontzientzia hartzeak ez du esan nahi euskara komunikazio hizkuntza bat bilakatu denik. Maila horretan elkarte munduak indar berezi bat egin du bere ekintza, mobilizazio eta praktikekin, hala nola, ikastolen sorkuntzarekin. Ikusi daitekenez, txosten horien egileek ez zuten 1991an egin zen inkesta soziolinguistikoaren daturik eta egiten zituzten oharrak beraien esperientzietatik eta intuizioetatik ateratzen zituzten. 


\section{Euskarazko irakaskuntzaren garapena}

Era berean, txostenaren egileek diote irakaskuntza elebidunean dabiltzan ikasleak gero eta gehiago direla, gizartean dagoen eskaera sozial nabarmena erakutsiz. Ama eskolan eta lehen mailan eskolatuak diren ikasleen $\% 80 \mathrm{ak}$ eta \%86ak frantses hutsean ikasten badu, gero eta guraso gehiagok irakaskuntza elebiduna autatzen dute, batik bat aukera dutelarik. Horrek erakusten du euskarazko irakaskuntza eskaintza ez dela nahikoa. Arazoa da sail elebidun gehienak Lapurdi hegoaldean kokatzen direla. Eta egoera aldatzeko ez bada ezer egiten, Ipar Euskal Herria bitan zatituko da. Batetik, Lapurdi hegoaldea dago non haurrek euskara ikasteko aukera ukanen duten beraien gurasoek sail elebidunetan eskolatzeko aukera ukanen baitute. Bestetik, gainontzeko lurraldea dago non euskara erabiltzeko aukerak murriztuko diren ez baita eskolarik egongo eta familia transmisioak berantz egingo baitu. Ondorioz, urrengo urteetan sortuko diren gelak lurraldea orekatu behako dute euskarazko irakaskuntza eskaintzari dagokionez. Orohar, hizkuntza politika baten sorrera premiazkotzat jotzen da.

\section{Helduendako irakaskuntza mugatua}

Prospektibaren arabera, AEKko klaseak jarraitzen dituzten ikasleen kopurua 566tik 827ra pasa da 1981 eta 1993ren artean. Nahiz eta garapen bat egon, soilik helduen \%0,5ak euskarazko klaseak jarraitzen ditu Ipar Euskal Herri osoan. Ikasle gehienak Lapurdi barnekaldean eta kostaldean kokatzen dira, Baxe-Nafarroa zein Xiberoa maila ertainean daudelarik.

\section{Diru gutxi euskal kulturarentzat}

Era berean, azpimarratzen dute kulturari sagaratua den diru-laguntzetatik soilik \%14a euskal kulturari ematen zaiola, jakinik erakustokiek \% 17,5a jasotzen dutela, teatroek \%12a eta hedapen kulturalek \%11a. Beraz, euskal kultura atzerriko kultura bat bezela ikusia da, ez zaiolako behar duen dirua ematen, kontsiderazio falta agerian utziz.

\section{Eszenario prospektiboak}

Prospektibaren azken dokumentuak sei eszenario aurkezten ditu non diagnostikoan agertu diren joera nagusien bilakaerak zehazten dituen, baita egoera kontrastatuagoak ere. Maiz agertzen diren hondamendi eszenarioa eta egitasmo eszenarioa alde batera utziak izan dira aukera desberdinak agerta- 
raziz, errealitatearen konplexutaxuna eta aniztasuna agerian utziz. Hiru eszenario bereizten dira :

- eszenario tendentzialak erakusten digu zer gertatuko den 2000. urtean ezer ez bada egiten,

- hiru eszenario kontrastatuek agerian uzten dute zer gertatuko den 2010. urtean ez bada politika orokor bezain partekatu bat martxan jartzen,

- bi eszenario boluntaristagoek, aldiz, esaten digute zer gerta daiteken neurriak hartzen badira eta garapen zein antolaketa egoki bat osatzen eta ondoren gauzatzen bada.

Lehen eszenarioan, prospektibaren egileek azpimarratzen dute gaur egongo joerek segitzen badute, batik bat hizkuntzaren eta kulturaren arloan, euskararen erabilera berantz joango dela eta kostaldea zein barnekaldearen arteko amildegia emendatuko dela.

\section{Hizkuntza antolaketa eskema}

Aipatutako Prospektibak jarraipen bat ukango du Euskal Herriko Garapen eta Antolaketa Eskemarekin. Modu adostuan osatua izan da, Estatuaren, Eskualdearen, Departamentuaren, lurralde kolektibitateen eta gizarte zibilaren ordezkarien parte hartzearekin. "Proposatzen duen geroaren ikuspegiarengatik, adierazten duen haundinahiarengatik, eskatzen duen konpromezuarengatik, Garapen eta Antolaketa Eskema egitasmo estrategiko bat da Euskal Herriarentzako hemendik 2010era. Asumitua den nortasun baten gainean finkatua izanik, Eskemak norabideak zehazten ditu eta helburuak zein egitarau operazionala ezartzen ditu“. Eskema erregularki berrikusia eta egokitua izango da lurraldearen erronkei aurre egiteko.

\section{Eskemaren arrazoinak}

\section{Prospektibatik Eskemara}

Antolaketa Eskema osatzerakoan, bere egileek Euskal Herria 2010 Prospektiba daukate baita Lurraldea deituriko lurralde egitasmoa ere, azken honek, Ipar Euskal Herriaren geroa egitura dezakeen funtsezko oinarriak zehazten dituelarik. Hortik abiatuz, Hautetsien Kontseiluak Garapen Kontseiluari eskatu zion hizkuntza atal bat ukango zuen Garapen eta Antolaketa Eskema bat osa zezan. Diagnostikotik ekintzara pasatzea nahi 
zen, nahiz eta ekintzen zerrenda batera ez mugatu. Zentzu horretan, Prospektibaren eta Lurraldearen gainean oinarrituz Eskema erregistroz aldatu da analisi kuadro espazial bat hobetsiz bai Ipar Euskal Herrian bai kanpoarekiko harremanetan. Aukerak egiteko ordua heldu da.

\section{Euskal Herriko politika publikoak norabidetzea}

Garapen eta Antoketa Eskema ez da aurretik finkatutako metodologia baten arabera egina izan, bere helburuak zein edukia argitzen joan baitira osatzearekin batera. Orohar, hiru ziren bere helburuak :

- Ipar Euskal Herriaren aldaketa boluntario baten dinamika zehaztea eta partekaraztea, beti ere testuinguru ekonomiko, sozial eta politikoan suertatu diren aldaketak kontutan hartuz. Eskemaren nahia koherentzia sistema bat baieztatzea da zeinek, urrengo hamar urteetan, Ipar Euskal Herria hunkituko duten aldaketei zentzua emango dien. Beraz, norabidea finkatzen du eta ez amaiera.

tokiko eragileen mobilizazio kolektibo bezain iraunkorra segurtatzea. Ez duenez legea aldatzeko eta ekintzak gauzatzeko gaitasunik, Eskemak neurriak zehaztuko dituen dokumentuak sortu eta norabidetu ditu. Ondorioz, Garapen eta Antolaketa Eskemak arauak eta ekintza kolektiborako kuadro estrategiko bat finkatzen ditu lurralde honetan dabiltzan eragileen konpromezu iraunkorrari esker.

- adostasun orokor bat bultzatzea. Lchendabiziko bi helburuak bete eta, Ipar Euskal Herriaren geroan inplikatuak diren eragileen engaiamendu zehatz bezain adostuak sortu ditu Euskal Herria Kontratua osatuz. Kontratu hau norabideek, deklinabide tematikoek, gauzatutako modeloek eta aplikapen hitzarmenek osatuko dute, jakinik hitzarmen horiek egitarauak, helburuak, obragintza sistemak eta diruztatzeak zehazten dituztela.

Ikuspegi orokor bat

Soilik helburu horietatik abiatuz uler daiteke Antolaketan Eskemaren kokapena eta mamia zeren bere helburua ez da Ipar Euskal Herriko erronka guztiak aipatzea ezta ere lurralde horretan burutuko diren politika publiko guztiak norabidetzea. Bakarrik, Ipar Euskal Herriari buruz ikuspegi orokorra daukaten egitasmo zein galderak kontutan hartzen ditu. Hori dela eta, Eskemaren helburua ez da antolaketa eta garapen egitarau oso bat zehaztea baizik eta eragile zein egitasmo desberdinei interpretazio kuadro bat eta koherentzia bat ematea, beti ere ikuspegi orokor batean oinarrituz. 


\section{Osatze kolektibo bat}

Eskema hau ez dute soilik adituek osatu, Ipar Euskal Herriko elkarte eta instituzio guztien inplikazioaren fruitua izan baita. Hala eta guztiz ere, Eskemak ez du unanimitatearen ilusioan erori nahi. Baina, osatzerakoan eta erabaki estrategikoak hartzerakoan, joan etorri askori esker, Eskemak Ipar Euskal Herriari buruzko ikuspegi desberdinak kontutan hartu ditu lurralde honen antolaketaren eta garapenaren haukera estrategikoa eginez.

\section{Egituraren apustua}

Hizkuntza atala daukan Garapen eta Antolaketa Eskema, ez da egitasmo sektorialen kokapen arrunta bat bezala egina izan. Ipar Euskal Herriko garapen dinamika espazialen ikuspegi komuna proposatzeko eta formalizatzeko haundinahiarekin osatua izan da ; ondoren, eragile bakoitzak bere arloan eta tokian gauzatu eta lagundu duelarik.

\section{Hizkuntza Antolaketa Eskema}

Euskal Herria 2010 Prospektibak eta Lurraldea txostenak argiki planteatu dituzte nortasun kulturalari loturiko erronkak eta nortasun horren garrantzia Ipar Euskal Herriaren garapenean. Euskararen erabilerari buruz bi ohar egiten dira : batetik, euskararen familia transmisioak ez duela gehiago eraginik eta, bestetik, azken 30 urteetan eginak izan diren indarrak euskarazko irakaskuntza garatzeko ez dutela familia transmisioaren gabezia ordezkatzen. Jakin behar da, euskarazko irakaskuntzak 9000 ikasle hunkitzen dituela 44000 ikasleren gainean eta 222 lanpostu sortu dituela 8537145 eurorentzat.

Irakaskuntzaren garapena funtsezkoa bada ez da nahikoa euskararen berreskurapena bermatzeko. Textuinguru honetan, euskararen ezagutza eta erabilera garatzeko hizkuntza politika egoki bat osatzea funtsezkotzat jotzen da, horrek hiru gauza suposatzen dituelarik : 1) denboran zehar kokatzen den eta berkonposaketa segurtatzen duen ekintza sakona, 2) euskara ikasteko gogoa bultzatzeko duen sustatze ekintza eta 3) neurri larriak euskara berbalorizatzeko.

\section{Euskarazko irakaskuntza bultzatzea}

1. Irakaskuntza elebidunaren eskaintza orokortzea. Eskemaren egileen arabera, duela 30 urte Ipar Euskal Herriak euskarazko irakaskuntza politika bat garatu du zein modelo bat bilakatu den Frantziako beste herri batzuentzat. Publikoak, pribatuak eta elkarteek euskarazko irakaskuntza eskaintza antola- 
tu dute eta, lan horri esker, 1990. hamarkada erdian ikasleen \%20ak euskara eskolan ikasi du, izan dadila murgiltze metodoan ala modelo elebidunean. Eskemak indar hori bi moduz indartzea zein norabidetzea proposatzen du :

a. Euskarazko irakaskuntza eskaintza modu adostuan garatzeko estrategia bat osatzea : 1) dauden hiru modelo pedagogikoen gainean oinarrituz eta modelo elebidunak hobetsiz, 2) lehentasuna lehen mailari emanez, eta 3) irakaskuntza honen jarraipena segurtatuz kolegiotik unibertsitatera. Baina, estrategia honek lurraldearen berezitasunak kontutan hartzea eskatzen du :

- landatze estrategia bat Baionako aglomerazioan non ikasleen \%40a kokatzen den eta non, modu bitxian, aukerak mugatuak diren,

- konsolidazio estrategia bat bitarteko zonaldean non euskarazko irakaskuntza gehien garatu den, nahiz eta eskaintza hori osatu behar den,

- eskaintzaren berkonposaketa estrategia bat barnekaldean non ikasle galerak nagusi diren eta non iniziazio modeloa orokortu den.

b. Euskarazko iniziazioaren eskaintza segurtatzea, horrek irakasleen kontratazioa baita pedagogia, ekipamentu eta logistika cgokiak lortzea suposatzen duelarik. Eskemak gomendatzen du :

- maixuen formakuntza eta kontratazio sailak azkartzea eta horretarako IUFMekin batera lan egitea beharrei aurre egiteko eta maîtres auxilliaires-en egoera erregularizatzeko,

- Ikas zentru pedagogikoaren egituraketa bizkortzea irakaskuntza sailen pedagogia sustengu erakunde bat bezela,

- ekipamenduen eta ahalmen logistikoen eraikuntza edota berbanaketa fagoretzea.

2. Helduei zuzendua dagoen euskarazko irakaskuntza eskaintza indartzea. Irakaskuntza honen eskaintza oso urria da euskararen erabilerak derrigortzen dituen erronkak kontutan hartuta eta errekurtso humano, tekniko zein materailak mobilizatzea ezinbestekoa da.

\section{Paisaje linguistikoa berkonposatzea}

1. Euskarazko seinalekuntza garatzea. DDEren eta Kontseilu Orokorraren bidez, bide departamentalei dagokionez, seinalekuntza elebiduna jadanik martxan da 90. hamarkadaz geroztik. Mugimendu honen haunditzeak zein koordinatzeak zerbitzu eta bide informazioan oinarritutako 
seinalekuntza elebidun plan bat osatzea eskatzen du : 1) Euskal Kultur Erakundeak (EKE) osatu dituen aplikapen oinarri orokorrak erreferentzia gisa hartuz eta 2) interbentzio egitarau bat finkatuz.

2. Euskarazko komunikabideen sorkuntza eta berkonposaketa sustengatzea. Euskarazko komunikabideak, irakaskuntzarekin eta seinalekuntzarekin batera, funtsezkoak dira hizkuntza antolaketan, jakinik hiru garapen ardatzek norabide tematiko hau egituratzen dutela :

- irrati egitasmoaren sorrera sustengatzea 80. hamarkadaz geroztik existitzen diren hiru irratien gainean oinarrituz. Ipar Euskal Herri osoa hunkitzen duten irrati horiek tokiko eskaera bati erantzuten diete. Egitasmo kolektibo horrek une berean egiturak profesionalizatu nahi ditu eta errekurtso zein ahalbideak amankomuntzen ditu.

- Euskal Kultura Sustengatzen duen Herrienarteko Sindikatarekin batera, irrati publiko euskaldun baten sorrera bultzatzea Radio France-en barnean.

- euskarazko emankizunen ekoizpena eta hedapena bultzatzea, France 3 Pays Basque eta Euskal Telebistaren gainean oinarrituz, baita ere bi kateen arteko trukaketa zein koekoizpenerako protokoloak martxan ezarriz.

3. Elebitasuna zerbitzu publikoetan garatzea. Euskara, zerbitzu publikoetan erabili daiteken tresna izan behar da eta horrek eskatzen du, 1) harrera guneetan, seinalekuntzan zein administrazioko idazkietan elebitasuna garatzea eta 2) toki publikoetan euskaraz hitzegiteko haukera eskaintzea. Baina, ikuspegi honetan bi ekimen nagusi bete behar dira. Batetik, herriko etxeetako zerbitzu publikoetan euskara ikasteko bidea bultzatzea, egitasmo hau gauzatzeko lehen betekizuna baita. Egunero erabiltzen diren hurbileko zerbitzu horiek abiapuntu hoberenak dira egokitzeko errexak baitira eta neurri horiek eragin haundia sor dezaketelako herritarretan eta beste zerbitzu publikoetan. Bestetik, interes orokorreko zerbitzu anizdun zentruen sorkuntza baliatzea.

Baina, azpimarratzekoa da Hizkuntza Antolaketa Eskemak egile ugari mobilizatu dituela eta ez dela obratze soil bat. Hizkuntza antolaketa gauzatu ahal izateko lau baldintza bete dira : 1) egile desberdinen arteko konzertazio iraunkorra bermatzea eta hauen ekimena koordinatzea, 2) hizkuntza politikaren sustapena bermatzea, bereziki eskolako irakaskuntzari dagokiona, 3) gauzatzen diren plangintzen jarraipena eta ebaluaketa egitea, beharrezko zuzenketak proposatuz eta 4) euskararen estatutuari doazkion erabakiak gauzatzen laguntzea. 


\section{Euskal herriko hitzarmen berezia}

\section{Hitzarmen Bereziaren hasera}

\section{Testuinguru historikoa}

Euskal Herriko Hitzarmen Berezia ulertzeko ezinbestekoa da Euskal Herria 2010 Prospektiba baita Garapen eta Antolaketa Eskema kontutan hartzea, jakinik, 1997ko abenduaren 15ean, CIADTri aurkeztu ostean, Estatuak Garapen Hitzarmen batean gauzatzea erabaki duela. Hitzarmen horren helburua segidan gauzatu daitezken neurriak hastea eta sustengatzea da Estatu-Eskualde Plan Kontratua izenpetu arte.

\section{Garapen Hitzarmena}

1997ko egitarauak aurreikusten zuen, hitzarmenak, ondare eta kultura arloko ekintzak indartzea. Hitzarmenak aurreikusten zuen 2000-2006 Plan Kontratuak jarraipena hartuko zuela ekintza berrien diruztatzea segurtatuz. Hala izan dadin, 1998 eta 2000. urtean, Garapen Kontseiluak eta Hautetsien Kontseiluak, Estatuarekin, Eskualde Kontseiluarekin, Kontseilu Orokorrarekin eta Baiona-Angelu-Biarritze Distriktoarekin hitzegin baita negoziatu du Ipar Euskal Herriaren ekarpena zehazteko Antolaketa Eskemaren ardatzen inguruan, geroztik gertatu diren aldaketak kontutan hartuz.

\section{Estatu-Eskualde Plan Kontratua}

Estatu-Eskualde Plan Kontratuak hainbat neurri diruztatzea aurreikusten du, eta, lurraldearen antolaketa zein garapen iraunkorreko norabide legearen aplikapenean, Plan Kontratuaren lurralde atalak egitasmo lurraldeen sustengu orokorra eta adostutako politika proposatzen ditu. Ipar Euskal Herriak herrien osatze desmartxa aspalditik aurreikusi du eta Estatuak ezagutzen duen lurralde bat ukaiteaz gain Garapen eta Antolaketa Eskema batez gozatzen du. 2000ko maiatzaren 18ko CIADTak Akitania Eskualdeko Prefetari eta Pirineo-Atlantikoetako Prefetari eskatu die, Eskualdearekin, Departamentuarekin eta Hautetsien Kontseiluarekin, Hitzarmen Berezi bat osa eta ondoren negozia dezaten.

\section{Hitzarmen Bereziaren osaketa}

Horrelako Hitzarmen bat eratzeko, metodologia zehatza osatzea eta ondoren gauzatzea ezinbestekoa zen. Izan ere, Estatuak kudeaturik, eragile instituzional guztiak batuak izan ziren proposamenak formalizatzeko, beti ere Euskal Herriko Garapen eta Antolaketa Eskematik abiatuz eta jakinik 
2000. urtean ebaluaketa bat egingo zela. Ondoren, Estatuaren eta lurralde kolektibitateen zerbitzuek teknikoki jorratu dituzte eta, lan hori amaitu ondoren, erabaki guneetara eraman dute.

Bestalde, Ipar Euskal Herrian burutzen ari den ekintza publikoaren ulergarritasuna hobetu nahiz, lurralde osoa kontutan hartzen du, Baionako aglomerazioa barne. 1997an definituak diren norabide orokorretan erabat kokatzen dira baita adostuak izan daitezken neurrien inguruan egituratuak ere, Eskematik etortzen direla ala CIADTek ordurarte gutxi jorratu dituen arloak izan daitezela. Zentzu horretan, Hitzarmen Berezia bi helburuetan kokatzen da : 1) Ipar Euskal Herria euro-eskualdearen lurralde estrategikoa izatea eta 2) bere barne kohesioa mantentzea zein azkartzea.

Proposatutako neurri bakoitzarentzat, aurreikusitako dirutza bat zehaztu da, diruemaileak dirutza bat ematera engaiatzen direlarik, beti ere aurretik finkatutako mugen barruan, jakinik Estatuarentzat Hitzarmenean agertzen diren konpromezuak lege finantzamentuen irikidurari baldintzatuak daudela. Baina, kasuen arabera, parte hartze horien kopuru orokorrak ekintza erabat diruztatzen du, Estatua, Departamentua ala Eskualdea obralari direlarik ala, beste erakundeekin batera, obralariaren autofinantzamentua osatzen dutelarik.

Bide erdian, esan nahi baita 2003an, ebaluaketa bat egin da, are gehiago dakigunean zenbait neurri 2003an gelditzen direla. Hor da adibide gisa euskal irratien kasua. Beraz, egitarauen gauzatzearen eta agertzen diren beharren arabera, beti ere adostasun desmartxa errespetatuz, orekatze bat aurkitu da.

\section{Hitzarmen Bereziaren edukia}

Hitzarmenaren edukiari dagokionez, 9 ataletan banatzen diren 70 neurri agertzen dira : 1) hizkuntza politika, 2) kultura, 3) ingurugiroa, 4) laborantxa, 5) arrantza, 6) industria eta formakuntza profesionala, 7) turismoa, 8) infraestrukturak eta urbanismoa eta 9) mugazgandia. Ekintza guztien kostu orokorra 400 milloi eurotakoa da ondorengo diru engaiamenduekin :

\section{1,502 milioi euro Estatuarentzat,}

26,573 milioi euro Eskualde Kontseiluarentzat, 123,995 milioi euro Kontseilu Orokorrarentzat.

Hitzarmen Berezia hizkuntza atalarekin hasten da egileek lehentasuna ematen baitiote. Bere gain hartzen ditu 1997an Hizkuntza Antolaketa Eskemak egiten dituen oharrak. Eskema hori aukera izan da euskara berreskuratzeko plan bat osatzeko Fishmanek egindako gomendioak bereganatuz. 
Bere aburuz, lurralde batean hizkuntza asko daudenean sei etapa jarraitu behar dira zailtasunean dagoen hizkuntza balorizatzeko.

Ondorioz, funtsezko galdera euskara sustengatzeko hizkuntza politikaren obragintza publikoarena da, zeren eragile guztiek onartzen badute euskara gizadiaren ondarearen zati bat dela eta orain arte onartuak izan diren neurriak ez direla nahikoak euskararen galera gelditzeko, ezin daiteke euskararen garapena elkarte eta botere publikoen arteko harreman gatazkatsuei eta militanteen lanari utzi. Hala eta guztiz ere, funtsezkoa da elkarte munduak urteetan zehar egin duen lana ezagutzea, kapitalizatzea eta desmartxa boluntarista bezain eraginkor batean kokatzea".

Bestalde, Eurokartari buruzko eztabaidak ala Poignant txostenak bi osagai argitu ditu, batetik, tokiko hizkuntza ez dela lurralde kolektibitate bakar baten gaitasuna eta, bestetik, legean ezerk ez diela debekatzen hizkuntza politika bat martxan jartzea.

Azkenik, 2000ko apirilean, Garapen Kontseiluak Antolaketa Eskemari buruz egindako ebaluaketak agerian ezarri du euskararen aldeko hizkuntza politika baten beharra. Horrek, Hitzarmen Bereziaren egileak funtzioetan eta ez egituretan oinarrituta dagoen dispositibo bat osatzera eraman ditu Eskemaren proposamen batzuk bere gain hartuz.

Botere publikoen esku izango den hizkuntza politika bat definitzea, obragintza publiko horrek Estatua, Eskualdea, Departamentua eta herriko etxeak (Euskal Kultura Sustengatzen duen Herrienarteko Sindikatak ordezkaturik) batzen dituelarik. Egitura honen eginbeharrak dira : 1) euskararen alde martxan jarri behar den hizkuntza politikaren oinarriak zehaztea, 2) ahalbideak mobilizatzea eta 3) gauzatu behar diren egitasmoak finkatzea.

Obragintza Publikoari lotua, hizkuntza eragile guziak batuko dituen Hizkuntza Kontseilu bat sortzea aurreikusten da, koordinazio, behatoki, proposamen eta ebaluaketa egitekoekin.

Ibilmolde ahalbideekin negoziatutako kargu txostenen gainean oinarrituz eta ebaluaketa erregularrak eginez, obralari publiko ala pribatuak hautatzea egitasmoak gauzatzeko asmoz.

Horrek, Hitzarmen Berezian adostutako hamar ekintzetara garamatza :

Hizkuntza Kontseilua sortzea,

Euskara eskolan ikasteko sensibilizatzea,

Eskolari loturiko eragile euskaldunak sustengatzea, Formakuntza iraunkorreko eragileak profesionalizatzea, 
Euskaltzaindiaren ikerketa programak sustengatzea,

Euskararen Ikerketa Zentruaren kokapena bermatzea,

Euskarazko material pedagogikoaren ekoizpena segurtatzea,

Euskal irratiak egitasmo komun batera gidatzea eta euskararen presentzia tokiko irratietan eta telebistetan garatzea,

Lurralde osoan, ETBren jasotze baldintza onak segurtatzea,

Euskara interneten garatzeko laguntza fondo bat martxan jartzea.

\section{Amaiera}

Ipar Euskal Herrian osatzen ari den hizkuntza politikak ez du zer ikustekorik Katalunian gauzatu denarekin. Izan ere, 1978ko Konstituzioaren 3. artikuak dio : "Espainiako beste hizkuntzak koofizialak direla Autonomia Erkidego bakoitzean, beraien estatutuaren arabera. Espainiako forma juridiko desberdinen aberastasuna ondare kultural bat da, babestua izango dena eta errespetu berezi batez gozatuko duena". 1979an onartu den Autonomi Estatutua argiagoa da oraino: 1) Kataluniako hizkuntza berezia katalana da, 2) katalana Kataluniako hizkuntza ofiziala da baita gaztelera ere, Estatu españoleko hizkuntza ofiziala, 3) Generalitateak bi hizkuntzen erabilera normala eta ofiziala segurtatzen ditu, neurriak hartuko ditu bere ezagutza segurtatzeko eta baldintzak sortuko ditu Kataluniako biztanleen eskubideen eta eginbeharren berdintasuna ziurtatzeko.

Baina, Kataluniako Autonomia Estatutuaren errespetuak hizkuntza politika osatzeko eta ondoren gauzatzeko instituzio berrien sorrera suposatzen zuen. Horregatik, 1980ean, Gobernu Katalanak, bere Kultura Sailean, Hizkuntza Politikarako Zuzendaritza Orokorra sortu zuen zein hiru zerbitzutan banatzen den : Soziolinguistika Katalanaren Institutua, Hizkuntza Kontseiluaren zerbitzua eta Katalanaren Erabileraren Normalizazio zerbitzua. Azken honek, hainbat sensibilizazio kanpaina abiarazi ditu, besteak beste 1981 eta 1982an burutuak izan direnak Kataluniako hizkuntza normalizaziorako. Bere esloganak zion : katalana, denon afera da. Ondoren, beste asko izan dira, hala nola hizkuntza normalizaziorako legearen hedapena lortu nahi zuena.

Une berean, Generalitateak hainbat egokipen ekarri dizkio legeari zeren, dekreto, orden eta adierazpen anitz hartzeaz gain, Llei de Normalizacio Linguistica a Catalunya legea onartu du 1983ko apirilaren 23an. Lan soziolinguistiko eta juridiko sakon batean adostutako lege honen helburua katalanaren normalizazioa segurtatzea da. Bere 2. artikuluak katalanaren erabilera eskubidearen marko orokorra finkatzen du katalanaren ira- 
kaskuntzaren bidez, elebitasun ezdiglosiko batera iritxi nahiz. Lege honek normalizazioaren bidea indartzen du hizkuntza bereziaren konzeptua onartaraziz ez baita hizkuntza koofizialera mugatzen. Hori dela eta, Generalitateak zilegitasun zein askatasun haundiagoa dauka katalanaren aldeko neurriak hartzeko.

Hala ere, egoera ez da idealizatu behar zeren, telebistan katalanak toki oparoa badauka katalan hutsean dabiltzan bi kateei esker eta kate espainolek egiten dituzten indarrei esker, irratiak eta prentsa idatziak nagusiki gaztelera erabiltzen baitute. Liburugintzaren egoera askoz hobea da kontutan izanik 1975ean 590 liburu katalanez argitaratzen baziren, 1987an 4145 liburu argitaratzen zirela hizkuntza horretan. Era berean, katalanak presentzia nabaria dauka espazio publikoan, jakinik seinalebide, plaka edota afitxa gehienak katalanez direla eta, gutxienez, katalanez eta gazteleraz.

Preseski, katalanaren tokia gizartean sustatu nahiz, Hizkuntza Politikarako Zuzendaritza Orokorrak hizkuntza politikaren hainbat inkesta zein ebaluaketa burutu ditu. Diotenez, politika horrek eraginik eduki du, batez ere irudien eta jarreren mailan baita katalanaren erabileran ere. Horrela, 1975ean, \%25,7ak ez zuen katalana ulertzen, \%74,3ak ulertzen zuen, $\% 53,1$ ak hitzegiten zuen eta $\% 14,5 \mathrm{ak}$ idazten zuen. 1986an ordea, biztanlegoaren \%11ak soilik ez zuen ulertzen, \%90,3ak ulertzen zuen, \%59,8ak hitzegiten zuen eta $\% 30,1 \mathrm{ak}$ idazten zuen. Zenbaki horiek aldaketa kantitatibo zein kalitatibo nabarmena agerian uzten dute. Aitzitik, hiriguneetan burutu diren beste inkesta batzuek erakutsi dute espainiako beste eskualdeetatik eta kanpotik zetozen pertsonek zailtasun gehiago zituztela katalana menperatzeko. Halaber, nahiz eta katalana eskolan ikasi, gazte askok gaztelerara jotzen dute lagun arteko harremanetan.

Orohar, esan daiteke Generalitateak burutu duen hizkuntza politikak katalana berreskuratze prozesu batean ezarri duela, moderazioarekin eta kontsentsuarekin egina izan baita. Gaur egun, Hizkuntza Politikarako Zuzendaritza Orokorrak etapa berri bat gainditu nahi du katalanari lehentasun osoa emanez. Zentzu horretan, Kataluniako adibidea interesgarria izan daiteke Ipar Euskal Herriko hizkuntza politika indartzeko orduan. 


\section{Bibliografia}

Aracil. LL.V. Conflit sociolinguistique et normalisation dans l'Europe nouvelle. Nancy, CEU, 1965.

Arcacil. LL.V., Papers de sociolingüistica. Barcelona, Edicions de la Magrama, 1982.

Bastardas i Boada. A., "L'aménagement linguistique en Catalogne au XXè siècle", in Maurais. J., Politique et aménagement linguistiques, Québec, Conseil de la Langue Française, 1985.

Blanchet. P., "Pour la reconnaissance du droit des locuteurs à disposer de leur idiome". Langage et société, Paris, nº55.

Blanchet. P., Langues, cultures et identités régionales. La métaphore de l'aïoli. Paris, L'Harmattan, 2002.

Blanchet. P., Breton. R., et Schiffman. H., Les langues régionales de France: un état des lieux à la veille du XXIè siècle. Louvain, Peeters, 1999.

Boyer. H., Langues en conflit. Paris, L'Harmattan, 1991.

Boyer. H., Eléments de sociolinguistique. Langue, communication et société. Paris, Dunod, 1996.

Boyer. H., Sociolinguistique: territoire et objets. Neuchâtel, Delachaux et Niestlé, 1996.

Bourdieu. P., Ce que parler vent dire. Paris, Fayard, 1982.

Calvet. L.J., La guerre des langues et les politiques linguistiques. Paris, Payot, 1987.

Certeau de. M., Julia. D., et Revel. J., Une politique de la langue. La Révolution française et les patois: l'enquête de Grégoire. Paris, Gallimard, 1975.

Club de Prospective Pays Basque 2010. Le Pays Basque en perspective. Juin 1994.

Conseil de Développement du Pays Basque, Schéma d'Aménagement et de Développement du Pays Basque: orientations stratégiques. Bayonne, octobre 1996.

Conseil de Développement du Pays Basque. Le Pays Basque à mi-parcours entre 1992 et 2010. Mars 2003.

Convention Spécifique Pays Basque 2001-2006, Bayonne, 22 décembre 2000. 
Etudes de sociolinguistique appliquée. Politiques linguistiques, $n^{\circ}$ 65, 1987.

Ferguson. C.A., "Diglossia", Word, n¹5, 1959.

Fishman. J.A., Sociolinguistique, Paris, Nathan, 1971.

Garmadi. J., La sociolinguistique. Paris, PUF,1981.

Hagège. C., Le français et les siècles. Paris, Odile Jacob, 1987.

Héran. F., Filhon. A., Deprez. C., "La dynamique des langues en France au fil du XXè siècle". Population et sociétés, n³76, février 2002.

Insee Aquitaine, "Les langues parlées en Aquitaine: la pratique héritée", $n^{\circ} 110$, septembre 2002.

Institut CSA. Les parents d'enfants de 0 à 2 ans du BAB et l'apprentissage de la langue basque. Paris, octobre 2001.

Labov. W., Sociolinguistique. Paris, Minuit, 1976.

Lafont. R., "Un problème de culpabilité sociologique: la diglossie francooccitane". Langue française, $\mathrm{n}^{\circ} 9,1971$.

Langages, "Bilinguisme et diglossie", n61, 1981.

Langue française. "L'enseignement des langues régionales", n²5, 1975.

Pietro. J.F., "Vers une typologie des situations de contacts linguistiques". Langage et société, n ${ }^{\circ} 43,1988$.

Plourde. M., La politique linguistique du Québec, 1977-1987. Québec, Institut québecois de recherche sur la culture, 1988.

Rouquette. R., Le régime juridique des langues en France. Thèse de Doctorat, Université de Paris X-Nanterre, 1987.

Tudela. J., El futur del català. Una radiografia sociolingüistica. Barcelona, Publicaciones El Mon, 1986.

Urteaga. E., "L'évolution de l'usage de la langue basque au Pays Basque français". Revue de Sociolinguistique: Bat, n ${ }^{\circ} 3$, pp. 51-63, Andoain, juin 2002.

Urteaga. E., "La politique linguistique au Pays Basque français". Revue de Sociolinguistique: Bat, $\mathrm{n}^{\circ} 45$, pp. 91-102, Andoain, décembre 2002.

Urteaga. E., "L'Eurocité Bayonne-Saint Sébastien et la langue basque". Revue de Sociolinguistique: Bat, ${ }^{\circ} 47$, Andoain, 2003. 
Urteaga. E., "La langue basque au Pays Basque: diagnostic, évolution et prospective". Lapurdum, n 7 , Bayonne, 2003.

Vallverdu. F., Aproximació critica a la sociolingüistica catalana. Barcelona, Edicions 62, 1980.

Vallverdu. F., El conflicto lingüistico en Cataluña: historia y presente. Barcelona, Península, 1981.

Wardhaugh. R., An introduction to Sociolinguistics. Oxford, Basil Blackwell $\mathrm{Lt}, 1986$. 